\title{
Moral distress within neonatal and paediatric intensive care units: a systematic review
}

\author{
Trisha Prentice, ${ }^{1,2}$ Annie Janvier, ${ }^{3}$ Lynn Gillam, ${ }^{2,4}$ Peter G Davis ${ }^{5,6}$
}

\begin{abstract}
${ }^{1}$ Neonatal Intensive Care Unit, Royal Children's Hospital, Parkville, Victoria, Australia ${ }^{2}$ Melbourne School of Population and Global Health, University of Melbourne, Melbourne, Victoria, Australia ${ }^{3}$ Division of Neonatology and Clinical Ethics, University of Montreal, Montreal, Quebec, Canada

${ }^{4}$ Children's Bioethics Centre, Royal Children's Hospital, Melbourne, Victoria, Australia ${ }^{5}$ Department of Newborn Research, The Royal Women's Hospital, Melbourne, Victoria, Australia

${ }^{6}$ Department of Obstetrics and Gynaecology, University of

Melbourne, Melbourne,

Victoria, Australia
\end{abstract}

\section{Correspondence to} Dr Trisha Prentice, Neonatal Intensive Care Unit, Royal Children's Hospital, 50 Flemington Road, Parkville, Melbourne 3051, Australia; prenticet@student.unimelb. edu.au

Received 20 July 2015 Revised 4 December 2015 Accepted 9 December 2015 Published Online First 22 January 2016

\section{ABSTRACT}

Objective To review the literature on moral distress experienced by nursing and medical professionals within neonatal intensive care units (NICUs) and paediatric intensive care units (PICUs).

Design Pubmed, EBSCO (Academic Search Complete, CINAHL and Medline) and Scopus were searched using the terms neonat ${ }^{*}$, infant ${ }^{*}$, pediatric ${ }^{*}$, prematur ${ }^{*}$ or preterm AND (moral distress OR moral responsibility OR moral dilemma OR conscience OR ethical confrontation) AND intensive care.

Results 13 studies on moral distress published between January 1985 and March 2015 met our inclusion criteria. Fewer than half of those studies (6) were multidisciplinary, with a predominance of nursing staff responses across all studies. The most common themes identified were overly 'burdensome' and disproportionate use of technology perceived not to be in a patient's best interest, and powerlessness to act. Concepts of moral distress are expressed differently within nursing and medical literature. In nursing literature, nurses are often portrayed as victims, with physicians seen as the perpetrators instigating 'aggressive care'. Within medical literature moral distress is described in terms of dilemmas or ethical confrontations.

Conclusions Moral distress affects the care of patients in the NICU and PICU. Empirical data on multidisciplinary populations remain sparse, with inconsistent definitions and predominantly small sample sizes limiting generalisability of studies. Longitudinal data reflecting the views of all stakeholders, including parents, are required.

\section{INTRODUCTION}

Moral distress refers to the anguish experienced when an individual makes a clear moral judgement about what action he/she should take but is unable to act accordingly due to constraints (societal, institutional or contextual). This is the 'essence' of Jameton's original definition. ${ }^{1}$ Moral residue refers to the lingering feelings that remain once the morally distressing situation has passed. ${ }^{2}$ In the adult nursing setting, moral distress has been implicated in compromising personal integrity, ${ }^{3-5}$ creating dissatisfaction within the workplace environment, ${ }^{4}$ contributing to burnout of staff $^{6}$ and ultimately having a negative impact on patient care. Neonatal intensive care units (NICUs) and paediatric intensive care units (PICUs) are highpressure environments where technology creates potential for burdensome care with limited perceived benefits in vulnerable populations, such as described in the fictional cases of Kevin and Mary

\section{What is already known on this topic}

- Most studies on moral distress focus on nurses in adult settings.

- Moral distress affects personal well-being, job retention and patient outcomes.

\section{What this study adds}

- Moral distress appears to affect care in neonatal and paediatric settings.

- However empirical data on moral distress are sparse in these services.

- More extensive and longitudinal data on moral distress in these settings are needed.

in this paper. It is thus reasonable to expect that significant moral distress may exist in these settings. However, there is limited evidence on moral distress within neonatal and paediatric healthcare professionals. ${ }^{4}$ This systematic review first seeks to examine the empirical research that exists about the nature and degree of moral distress experienced within NICUs or PICUs. This is useful in documenting how moral distress is represented differently within different healthcare professionals. Following this, the paper raises questions about the nature of moral distress, who feels it and its ethical significance.

\section{METHODS}

The review was conducted using PRISMA (Preferred Reporting Items for Systematic Reviews and Meta-Analyses) guidelines. ${ }^{8}$

\section{Search strategy}

An electronic literature search of Pubmed, EBSCO (Academic Search Complete, CINAHL and Medline) and Scopus was performed using combinations and spelling variations of the following key words: neonat", infant*, pediatric*, prematur* or preterm AND (moral distress OR moral responsibility OR moral dilemma OR conscience OR ethical confrontation) AND intensive care. The last search was conducted on 1 April 2015. Reference lists of papers that underwent full-text analysis were scanned for additional studies. Furthermore, references from review articles on moral distress were scanned for eligible studies. The first author (TP) formulated the search terms and conducted the electronic search. The results from the different 


\section{Case 1}

Kevin, a preterm baby born at 23 weeks gestation, develops severe necrotising enterocolitis at 2 weeks of age. Additionally, Kevin has severe lung disease and is dependent on a ventilator for survival. He is taken to theatre where the surgeons declare that there is no viable gut left. Despite being informed of the poor prognosis, the parents refuse the recommendation for redirection of care to comfort care.

\section{Case 2}

Mary, a 2-year-old child, suffers profound hypoxic ischaemic encephalopathy after near-drowning. Both the brain MRI and clinical examination are consistent with an extensive brain injury that will result in profound disability should she survive. Additionally, Mary is suffering from multiorgan failure, including renal failure, due to the significant hypoxic insult. The medical team have counselled the family that redirection to comfort care is in Mary's best interest, due to the extensive brain and kidney damage. The parents are initially in agreement. However shortly after a nephrology consultant speaks to them about dialysis, they change their mind and want to continue 'full active management' for their daughter.

databases were merged and duplicates removed. Argument-based literature, editorials, commentaries, dissertations, letters and opinion pieces were excluded. Articles were limited to those published after 1984-the year the term 'moral distress' was first coined by Jameton. ${ }^{1}$ Studies were limited to those performed in an industrialised country setting and written in English. The term moral distress carries multiple meanings, is applied predominantly in nursing literature and is often conflated with other terms such as 'moral dilemma'. The authors were therefore careful to avoid inadvertently excluding articles based on titles alone where the concept of moral distress was expressed throughout the article. A large number of key words were therefore used, but only articles on the specific topic of moral distress, using the definition used in the introduction, were analysed. Articles were additionally limited to the perspectives of healthcare providers. Intervention studies to address moral distress were also excluded from the primary analysis as they assumed a particular framework of moral distress and did not add to knowledge on the nature or intensity of moral distress. Institutional reviews were excluded if there were insufficient details to enable subanalysis of paediatric or neonatal cohorts. The last author (PGD) reviewed the search strategy, the abstracts and full text articles. Where there was doubt over the inclusion/exclusion of an article, all authors discussed the issues until consensus was reached.

\section{RESULTS}

Two authors (TP and PGD) reviewed 26 full text articles. Of these, 13 met the inclusion criteria (see figure 1). A number of institutional reviews which included data from NICUs and PICUs were excluded where subanalysis of these groups was not provided. This included one of the largest studies by Whitehead et al, ${ }^{9}$ who interviewed 592 healthcare professionals from one large centre in the USA. Moral distress was present in all professionals with the greatest distress present in those involved in direct patient care. Given the limited number of studies, articles were not excluded on the basis of quality alone; however, the Critical Appraisal Skills Programme $(\mathrm{CASP})^{10}$ was used to review the quality of the included studies.

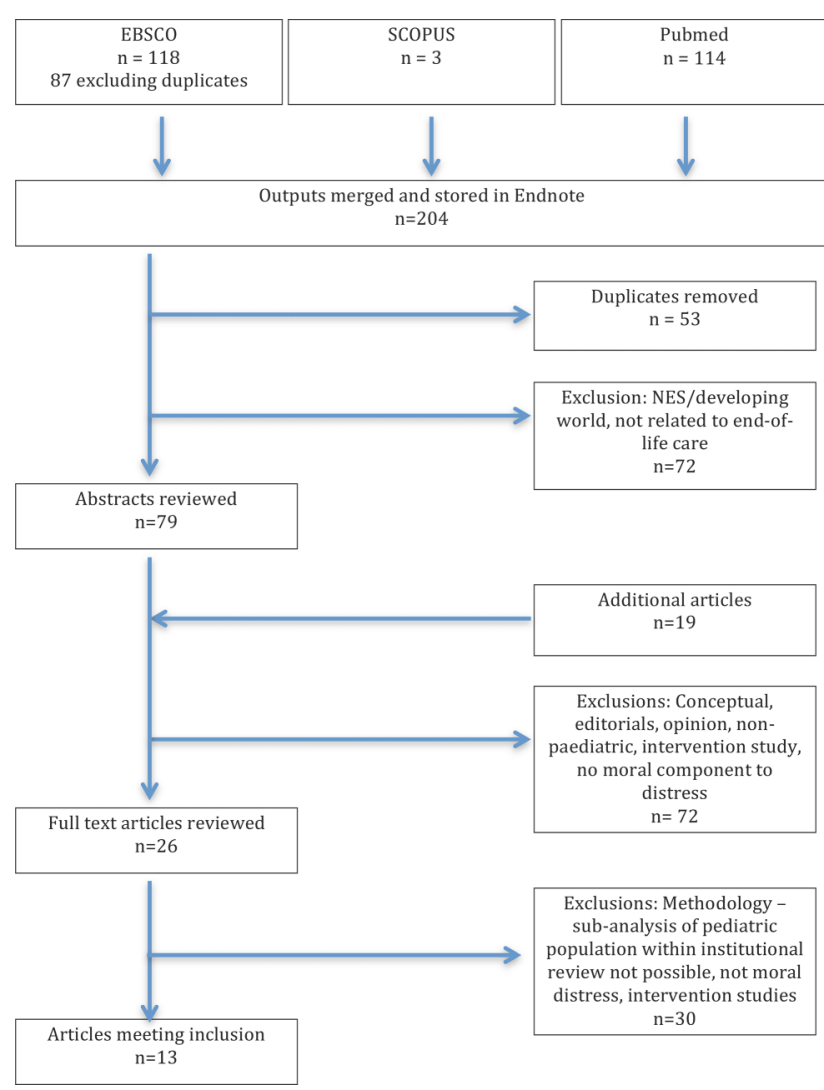

Figure 1 Literature review process.

\section{Methodological characteristics of studies}

The methodological characteristics and findings are summarised in table 1.

Six of the studies were multidisciplinary (involving at least two professions, including one study surveying medical students). Nursing is the most represented profession, reflecting the origins of moral distress theory as well as the relatively high ratio of nursing staff to other health professionals within a healthcare team. Five studies had a sample size of fewer than 30 interviews. Two of the included studies were secondary analyses where the initial surveys or focus groups did not set out to address moral distress, potentially limiting their scope. Five of the studies used a version of Corley's Moral Distress Scale (MDS).

Common themes represented included disproportionate care, 'aggressive' use of technology, powerlessness, and communication around life and death issues. Interestingly, moral distress is generally reported as occurring because a provider feels she/he is 'doing too much', as illustrated by the cases of Kevin and Mary. The converse is rarely reported as causing moral distress, for example, deciding for palliative care in the face of uncertainty. Concepts of moral distress are expressed differently within nursing and medical literature. In nursing literature, emphasis was often placed on the emotional or psychological component of moral distress. Nurses express a 'voicelessness' and 'powerlessness' within the constraints of the medical hierarchy. In contrast moral distress is described in terms of dilemmas or ethical confrontations within medical literature, considering questions such as: How, and by whom should decisions be made for children like Kevin and Mary? When is death more favourable than disability? How should these considerations be communicated to parents? More recently literature has examined the ethical climate of the unit and the interactions of 


\begin{tabular}{|c|c|c|c|c|c|c|c|c|c|}
\hline Author & Country & Target participants & No. & Methodology & Aims & Outcomes & Themes & Limitations & Recommendations \\
\hline $\begin{array}{l}\text { Hefferman } \\
\text { et } a l^{14}\end{array}$ & USA & $\begin{array}{l}\text { NICU staff } \\
\text { Nurses-initial } \\
\text { survey } \\
\text { Nurses-second } \\
\text { survey } \\
\text { Neonatologists } \\
\text { Respiratory care } \\
\text { supervisor } \\
\text { Advanced practice } \\
\text { nurses (Level III } \\
\text { NICU) }\end{array}$ & $\begin{array}{l}98 \\
24 \\
67 \\
3 \\
3 \\
1\end{array}$ & $\begin{array}{l}\text { Two qualitative } \\
\text { surveys- } \\
\text { convenience sample } \\
\text { — spaced two } \\
\text { months apart }\end{array}$ & $\begin{array}{l}\text { To explore ethical } \\
\text { dilemmas healthcare } \\
\text { professionals faced and } \\
\text { describe the impact, if } \\
\text { any, such dilemmas had } \\
\text { on their care or sense of } \\
\text { self as healthcare } \\
\text { providers } \\
\text { Explore whether } \\
\text { dilemmas elicit moral } \\
\text { distress }\end{array}$ & $\begin{array}{l}\text { Expressed moral distress } \\
\text { raises more questions } \\
\text { regarding resuscitation and } \\
\text { treatment of infants born at } \\
\text { 'edge of viability' } \\
\text { Difficult dilemmas can bring } \\
\text { about moral distress in } \\
\text { healthcare professionals }\end{array}$ & $\begin{array}{l}\text { - Advancing } \\
\text { technology } \\
\text { Disproportionate } \\
\text { care } \\
\text { Medical } \\
\text { hierarchy } \\
\text { - Decision-making }\end{array}$ & $\begin{array}{l}\text { Survey sought 'ethical } \\
\text { dilemmas' and the term } \\
\text { was used interchangeably } \\
\text { with moral distress } \\
\text { Initial survey results } \\
\text { made available to all } \\
\text { staff prior to second } \\
\text { survey } \\
\text { Unknown response rate } \\
\text { Unclear aims and } \\
\text { methodology }\end{array}$ & $\begin{array}{l}\text { Those experiencing moral } \\
\text { distress need to 'be given } \\
\text { a voice' in the } \\
\text { decision-making process }\end{array}$ \\
\hline $\begin{array}{l}\text { Solomon } \\
\text { et } a l^{11}\end{array}$ & USA & $\begin{array}{l}\text { Multidisciplinary } \\
\text { paediatric staff in } \\
\text { PICUs, medical, } \\
\text { surgical or } \\
\text { haematology/oncology } \\
\text { units. } \\
\text { Overall response rate } \\
64 \% \text { ( } 54 \%-71 \% \text { across } \\
\text { sites) } \\
\text { attending } \\
\text { physicians } \\
\text { - PICU attending } \\
\quad \text { physicians } \\
\text { 'house officers' } \\
\text { nurses } \\
\text { - PICU nurses } \\
\quad \text { (3 Children's } \\
\text { hospitals and } 4 \\
\text { general hospitals } \\
\text { with PICUs) }\end{array}$ & $\begin{array}{l}209 \\
25 \\
116 \\
456 \\
267\end{array}$ & $\begin{array}{l}\text { Quantitative } \\
\text { questionnaire, } \\
\text { population based } \\
\text { Based on the } \\
\text { Decisions Near } \\
\text { the End of Life } \\
\text { Institutional } \\
\text { profile }\end{array}$ & $\begin{array}{l}\text { To determine the extent } \\
\text { to which a variety of } \\
\text { healthcare professionals } \\
\text { are in agreement with } \\
\text { one another and with } \\
\text { published ethical } \\
\text { recommendations } \\
\text { regarding the } \\
\text { withholding and } \\
\text { withdrawing of } \\
\text { life-sustaining therapies } \\
\text { and the role of parents in } \\
\text { end-of-life } \\
\text { decision-making } \\
\text { To determine the extent } \\
\text { to which healthcare } \\
\text { professionals are } \\
\text { concerned with problems } \\
\text { of overtreatment }\end{array}$ & $\begin{array}{l}80 \% \text { of critical care } \\
\text { physicians and } 69 \% \text { of critical } \\
\text { care nurses reported acting } \\
\text { against their conscience and } \\
\text { 'saving children who should } \\
\text { not be saved' } \\
56 \% \text { of critical care } \\
\text { physicians and } 32 \% \text { of critical } \\
\text { care nurses reported feeling } \\
\text { that sometimes the treatment } \\
\text { they offer children is overly } \\
\text { burdensome }\end{array}$ & $\begin{array}{l}\text { Conscience } \\
\text { - Burdensome care }\end{array}$ & $\begin{array}{l}64 \% \text { response rate } \\
\text { Did not have a } \\
\text { probability-based sample } \\
\text { of institutions } \\
\text { Healthcare professionals } \\
\text { working solely in } \\
\text { neonates were excluded }\end{array}$ & $\begin{array}{l}\text { More research on } \\
\text { regard for the } \\
\text { dead-donor rule } \\
\text { More ethics education } \\
\text { required } \\
\text { More interdisciplinary } \\
\text { and cross-subspecialty } \\
\text { discussion of inherently } \\
\text { complex and stressful } \\
\text { paediatric end-of-life } \\
\text { cases }\end{array}$ \\
\hline $\begin{array}{l}\text { Janvier } \\
\text { et } a l^{12}\end{array}$ & Canada & $\begin{array}{l}\text { Nurses, } \\
\text { Residents } \\
\text { (University centre, } \\
\text { high-risk obstetric } \\
\text { service, maternity } \\
\text { hospital NICU, } \\
\text { outborn NICU) }\end{array}$ & $\begin{array}{l}115 \\
164\end{array}$ & $\begin{array}{l}\text { Quantitative } \\
\text { questionnaire, } \\
\text { population based }\end{array}$ & $\begin{array}{l}\text { To determine the frequency } \\
\text { of ethical confrontations } \\
\text { (using a moral distress } \\
\text { definition explicitly } \\
\text { described) and factors } \\
\text { associated with increased } \\
\text { frequency }\end{array}$ & $\begin{array}{l}\text { Moral distress was } \\
\text { experienced by } 35 \% \text { of } \\
\text { nurses and } 19 \% \text { of residents } \\
\text { Ethical confrontations are } \\
\text { influenced by knowledge } \\
\text { levels regarding outcomes of } \\
\text { preterm infants (more moral } \\
\text { distress when inaccurate } \\
\text { knowledge) } \\
\text { Ethical confrontations are } \\
\text { more frequent where there is } \\
\text { more cultural diversity. }\end{array}$ & $\begin{array}{l}\text { - Ethical } \\
\text { confrontations } \\
\text { - Knowledge }\end{array}$ & $\begin{array}{l}\text { Attending physicians not } \\
\text { included } \\
\text { Limited definition of } \\
\text { ethical confrontations } \\
\text { Only examined } \\
\text { overtreatment and not } \\
\text { undertreatment } \\
\text { component of moral } \\
\text { distress }\end{array}$ & $\begin{array}{l}\text { Ethical confrontation } \\
\text { may be unavoidable } \\
\text { and beneficial when } \\
\text { approached critically } \\
\text { and discussed as a } \\
\text { team } \\
\text { Further studies to equip } \\
\text { trainees and healthcare } \\
\text { workers with the tools } \\
\text { to examine } \\
\text { confrontations, to learn } \\
\text { from, and profit from } \\
\text { them }\end{array}$ \\
\hline
\end{tabular}




\begin{tabular}{|c|c|c|c|c|c|c|c|c|c|}
\hline Author & Country & Target participants & No. & Methodology & Aims & Outcomes & Themes & Limitations & Recommendations \\
\hline $\begin{array}{l}\text { Catlin } \\
\text { et }\left.a\right|^{27}\end{array}$ & USA & $\begin{array}{l}\text { Critical care nurses } \\
\text { Neonatal } \\
\text { - Paediatric }\end{array}$ & $\begin{array}{l}66 \\
53 \\
13\end{array}$ & $\begin{array}{l}\text { Pilot } \\
\text { Mixed methods, } \\
\text { convenience } \\
\text { sample } \\
\text { Multiple choice } \\
\text { and open-ended } \\
\text { surveys }\end{array}$ & $\begin{array}{l}\text { To verify the clinical use of } \\
\text { their concept of } \\
\text { conscientious objection in } \\
\text { cases of moral distress }\end{array}$ & $\begin{array}{l}\text { Analysis of conscientious } \\
\text { objection use in neonatal and } \\
\text { paediatric nursing care }\end{array}$ & $\begin{array}{l}\text { Ambivalence } \\
\text { towards } \\
\text { technology } \\
\text { Futility } \\
\text { Powerlessness } \\
\text { Fear of } \\
\text { consequences }\end{array}$ & $\begin{array}{l}\text { Defining conscientious } \\
\text { objection } \\
\text { Is conscientious objection } \\
\text { merely voicing a } \\
\text { difference of opinion or } \\
\text { refusing to follow } \\
\text { through? }\end{array}$ & $\begin{array}{l}\text { To direct research towards } \\
\text { interventions 'that will } \\
\text { prevent futile care as well } \\
\text { as to protect and defend } \\
\text { nurses from the pain of } \\
\text { powerless and participation } \\
\text { in such cases that appear } \\
\text { to harming patients' }\end{array}$ \\
\hline $\begin{array}{l}\text { Lee and } \\
\text { Dupree }^{18}\end{array}$ & USA & $\begin{array}{l}\text { PICU staff } \\
\text { (multidisciplinary) } \\
\text { (Single centre PICU) }\end{array}$ & 29 & $\begin{array}{l}\text { - Qualitative } \\
\text { descriptive study, } \\
\text { population based } \\
\text { - Semi-structured } \\
\text { interviews }\end{array}$ & $\begin{array}{l}\text { To describe the experiences } \\
\text { of PICU healthcare } \\
\text { professionals caring for a } \\
\text { child who dies and to } \\
\text { determine whether } \\
\text { healthcare professionals } \\
\text { experienced moral distress }\end{array}$ & $\begin{array}{l}\text { Grief was more prominent as a } \\
\text { response than moral distress }\end{array}$ & $\begin{array}{l}\text { Communication } \\
\text { - Accommodating } \\
\text { wishes of others } \\
\text { - Ambiguity about } \\
\text { technology use } \\
\text { Grief } \\
\text { Emotional } \\
\text { support }\end{array}$ & $\begin{array}{l}\text { Interviewed until } \\
\text { saturation of themes but } \\
\text { small sample of } 8 \\
\text { patients } \\
\text { Enrolled after deaths; ? } \\
\text { appropriate timing } \\
\text { Greater moral distress } \\
\text { associated with patients } \\
\text { that are thought to have } \\
\text { received disproportionate } \\
\text { care }\end{array}$ & $\begin{array}{l}\text { Communication; } \\
\text { interventions to } \\
\text { improve availability of } \\
\text { physicians to parents } \\
\text { Emotional support for } \\
\text { staff }\end{array}$ \\
\hline $\begin{array}{l}\text { Cavaliere } \\
\text { et } a l^{4}\end{array}$ & USA & $\begin{array}{l}\mathrm{RNs} \\
\mathrm{n}=196 \text { (48\% response } \\
\text { rate) } \\
\text { (2 level III NICUs) }\end{array}$ & 94 & $\begin{array}{l}\text { Quantitative, } \\
\text { descriptive, } \\
\text { correlational } \\
\text { study, } \\
\text { convenience } \\
\text { sample } \\
\text { MDSNPV (Moral } \\
\text { distress scale- } \\
\text { paediatric version) }\end{array}$ & $\begin{array}{l}\text { To describe moral distress of } \\
\text { RNs working in NICUs and } \\
\text { to identify the situations } \\
\text { associated with their moral } \\
\text { distress }\end{array}$ & $\begin{array}{l}\text { Moral distress, as identified } \\
\text { by MDS was infrequent and } \\
\text { low intensity } \\
\text { Mean intensity scores for top } \\
10 \text { distressing situations } \\
\text { ranged from } 1.71 \text { to } 3.18 \\
\text { Following family wishes to } \\
\text { continue when not in child's } \\
\text { best interest caused greatest } \\
\text { moral distress }\end{array}$ & $\begin{array}{l}\text { Continuing at } \\
\text { family's wishes } \\
\text { despite not 'best } \\
\text { interest' of } \\
\text { patient } \\
\text { - Powerlessness }\end{array}$ & $\begin{array}{l}\text { Analysis limited to items } \\
\text { within MDS } \\
\text { Homogenous } \\
\text { demographics of nursing } \\
\text { staff }\end{array}$ & $\begin{array}{l}\text { More studies required } \\
\text { using the MDSNPV to } \\
\text { refine tool } \\
\text { Exploration of more } \\
\text { heterogenous } \\
\text { populations to aid } \\
\text { generalisability }\end{array}$ \\
\hline $\begin{array}{l}\text { McGibbon } \\
\text { et } a l^{15}\end{array}$ & Canada & $\begin{array}{l}\text { PICU nurses } \\
\text { (Paediatric hospital) }\end{array}$ & 23 & $\begin{array}{l}\text { Qualitative study, } \\
\text { theoretical } \\
\text { sampling } \\
\text { Institutional } \\
\text { ethnography } \\
\text { In-depth } \\
\text { interviews, } \\
\text { participant } \\
\text { observation and } \\
\text { focus groups }\end{array}$ & $\begin{array}{l}\text { To reformulate the nature of } \\
\text { stress in nursing with } \\
\text { attention to contextual } \\
\text { aspects of nursing }\end{array}$ & $\begin{array}{l}\text { Nurses' stress is very much } \\
\text { related to the social relations } \\
\text { of power which may lead to } \\
\text { moral distress } \\
\text { Formulations of nursing stress } \\
\text { (including moral distress) } \\
\text { must reflect the dynamics } \\
\text { between the nurse, the } \\
\text { environment and surrounding } \\
\text { relationships and hierarchies }\end{array}$ & $\begin{array}{l}\text { Emotional } \\
\text { distress } \\
\text { - Burden of } \\
\text { responsibility } \\
\text { - Constancy of } \\
\text { presence } \\
\text { Bodily caring? } \\
\text { - Being mothers, } \\
\text { sisters, daughters } \\
\text { and aunts }\end{array}$ & $\begin{array}{l}\text { Convenience sample rather } \\
\text { than reaching saturation of } \\
\text { themes }\end{array}$ & $\begin{array}{l}\text { Conceptualisations of } \\
\text { nurse' stress including } \\
\text { occupational, moral } \\
\text { distress and traumatisation } \\
\text { require further } \\
\text { contexualisation }\end{array}$ \\
\hline Lawrence $^{21}$ & USA & $\begin{array}{l}\text { RNs } n=98(14 \% \\
\text { response rate) } \\
\text { NICU } n=90(8 \%) \\
\text { PICU } n=62(18 \%) \\
\text { MICU } n=46(22 \%) \\
\text { (3 ICUs) }\end{array}$ & $\begin{array}{l}28 \\
7 \\
11 \\
10\end{array}$ & $\begin{array}{l}\text { Quantitative, } \\
\text { descriptive, } \\
\text { correlation study, } \\
\text { convenience } \\
\text { sample } \\
\text { - Demographic } \\
\text { Data Collection } \\
\text { Tool } \\
\text { UWES } \\
\text { UDS (in part) } \\
\text { - CRPQ } \\
\text { - RRQ in part }\end{array}$ & $\begin{array}{l}\text { To examine how nurses' } \\
\text { moral distress, education } \\
\text { level and CRP related to } \\
\text { work engagement }\end{array}$ & $\begin{array}{l}\text { Negative direct relationship } \\
\text { between moral distress and } \\
\text { CRP. Positive direct } \\
\text { relationship between CRP and } \\
\text { work engagement } \\
\text { An increase in RN education } \\
\text { is associated with increase } \\
\text { CRP (in NICU) }\end{array}$ & $\begin{array}{l}\text { Education } \\
\text { Workplace } \\
\text { engagement } \\
\text { Moral distress } \\
\text { CRP }\end{array}$ & $\begin{array}{l}14 \% \text { response rate } \\
\text { Convenience sample } \\
\text { CRPQ not standardised } \\
\text { Only the 'not in the best } \\
\text { interest' frequency } \\
\text { subscale ( } 7 \text { items) was } \\
\text { used limiting the scope } \\
\text { of MD examined }\end{array}$ & $\begin{array}{l}\text { Strategies to promote } \\
\text { CRP and reduce moral } \\
\text { distress are } \\
\text { recommended, to } \\
\text { promote work } \\
\text { engagement } \\
\text { Further studies required } \\
\text { on the role of } \\
\text { education in nurses' } \\
\text { work engagement } \\
\text { recommend }\end{array}$ \\
\hline
\end{tabular}




\begin{tabular}{|c|c|c|c|c|c|c|c|c|c|}
\hline Author & Country & Target participants & No. & Methodology & Aims & Outcomes & Themes & Limitations & Recommendations \\
\hline $\begin{array}{l}\text { Sannino } \\
\text { et } a l^{17}\end{array}$ & Italy & $\begin{array}{l}\text { Nurses } \\
\mathrm{n}=472 \text { ( } 86 \% \text { response } \\
\text { rate) } \\
\text { (15 level III NICUs) }\end{array}$ & 406 & $\begin{array}{l}\text { Quantitative, } \\
\text { cross-sectional } \\
\text { questionnaires, } \\
\text { convenience } \\
\text { sample } \\
\text { MDSNPV-Italia }\end{array}$ & $\begin{array}{l}\text { To evaluate the } \\
\text { frequency, intensity and } \\
\text { level of moral distress } \\
\text { experienced by nurses } \\
\text { working in NICUs } \\
\text { To assess whether nurses } \\
\text { working in NICUs with } \\
>/=1000 \text { deliveries/year } \\
\text { experience a higher } \\
\text { frequency, intensity and } \\
\text { level of moral distress } \\
\text { than nurses working in } \\
\text { NICUs }<1000 \text { deliveries }\end{array}$ & $\begin{array}{l}\text { Low moral distress rate as } \\
\text { measured by MDS. Initiating } \\
\text { care when felt futile ranked } \\
\text { highest cause of moral } \\
\text { distress } \\
\text { No association between the } \\
\text { number of deliveries in a } \\
\text { centre and the moral distress } \\
\text { of nurses }\end{array}$ & $\begin{array}{l}\text { - 'Aggressive' use } \\
\text { of technology } \\
\text { without } \\
\text { perceived benefit } \\
\text { - Honouring } \\
\text { parental } \\
\text { decision-making }\end{array}$ & $\begin{array}{l}\text { Sample limited to Northern } \\
\text { Italy }\end{array}$ & $\begin{array}{l}\text { Further studies required in } \\
\text { neonatal context }\end{array}$ \\
\hline $\begin{array}{l}\text { Molloy } \\
\text { et al }\end{array}$ & Canada & $\begin{array}{l}\text { Nurses } \\
\text { (Tertiary academic } \\
\text { referral hospital) }\end{array}$ & 15 & $\begin{array}{l}\text { Qualitative } \\
\text { interviews, } \\
\text { convenience } \\
\text { sample } \\
\text { Secondary } \\
\text { analysis of data }\end{array}$ & $\begin{array}{l}\text { To increase understanding of } \\
\text { moral distress experienced by } \\
\text { nurses involved in the } \\
\text { decision-making regarding } \\
\text { resuscitation of neonates at } \\
\text { the margins of viability }(<25 \\
+6 \text { weeks) }\end{array}$ & $\begin{array}{l}\text { Nurses perceive a lack of power } \\
\text { and influence in the neonatal } \\
\text { resuscitation decision-making } \\
\text { process }\end{array}$ & $\begin{array}{l}5 \text { themes } \\
\text { contribute to } \\
\text { moral distress } \\
\text { - Uncertainty } \\
\text { - Questioning } \\
\text { informed } \\
\text { consent } \\
\text { - Differing } \\
\text { perspectives } \\
\text { - Harm and } \\
\text { suffering } \\
\text { - Being with the } \\
\text { family }\end{array}$ & $\begin{array}{l}\text { Secondary analysis- } \\
\text { analysis limited to } \\
\text { original data } \\
\text { Only } 15 \text { respondents }\end{array}$ & $\begin{array}{l}\text { Provide staff with } \\
\text { coping mechanisms } \\
\text { Engage more effective } \\
\text { communication } \\
\text { strategies } \\
\text { Additional research on } \\
\text { why nurses feel } \\
\text { helpless in } \\
\text { decision-making }\end{array}$ \\
\hline $\begin{array}{l}\text { Sauerland } \\
\text { et } a l^{7} \\
\text { (Part II) }\end{array}$ & USA & $\begin{array}{l}\text { Nurses working in } \\
\text { NICU/PICU and } \\
\text { intermediate care } \\
\text { settings } \\
\mathrm{n}=152 \text { (35\% response } \\
\text { rate) } \\
\text { (Academic safety net } \\
\text { hospital—provides } \\
\text { significant service to } \\
\text { lower socioeconomic } \\
\text { population) }\end{array}$ & 53 & $\begin{array}{l}\text { Quantitative } \\
\text { questionnaires, } \\
\text { convenience } \\
\text { sample } \\
\text { MDSNPV } \\
\text { Olson's HECS-S }\end{array}$ & $\begin{array}{l}\text { To explore perceptions of } \\
\text { moral distress, moral residue } \\
\text { and ethical climate among } \\
\text { registered nurses }\end{array}$ & $\begin{array}{l}\text { PICU and NICU nurses } \\
\text { experience less moral distress } \\
\text { than those in adult ICUs } \\
\text { Greatest distress caused by } \\
\text { inadequate staffing, } \\
\text { incompetent staff, performing } \\
\text { unnecessary tests and } \\
\text { treatments and continuing } \\
\text { life support when not in } \\
\text { child's best interest } \\
\text { Work climate was ranked as } \\
\text { moderately ethical }\end{array}$ & $\begin{array}{l}\text { Work climate } \\
\text { - Moral distress }\end{array}$ & $\begin{array}{l}\text { 35\% response rate } \\
\text { Single site } \\
\text { Lack of differentiation } \\
\text { between NICU/PICU } \\
\text { nurses and involvement } \\
\text { in critical care vs } \\
\text { intermediate setting }\end{array}$ & $\begin{array}{l}\text { Intervention studies that } \\
\text { address moral distress at } \\
\text { the individual, } \\
\text { intraprofessional/ } \\
\text { interprofessional } \\
\text { environment and hospital } \\
\text { policies }\end{array}$ \\
\hline $\begin{array}{l}\text { Trotochaud } \\
\text { et } a l^{19}\end{array}$ & USA & $\begin{array}{l}\text { Multidisciplinary } \\
\text { paediatric healthcare } \\
\text { providers } \\
\text { NICU nurses } \\
\text { NICU other } \\
\text { PICU nurses } \\
\text { PICU other } \\
\text { Overall response } \\
\text { rate ranged from } \\
26.3 \% \text { for } \\
\text { physicians across all }\end{array}$ & $\begin{array}{l}1113 \\
84 \\
38 \\
79 \\
47\end{array}$ & $\begin{array}{l}\text { Quantitative } \\
\text { descriptive study, } \\
\text { convenience } \\
\text { sample } \\
\text { MDS-R } \\
\text { Survey questions } \\
\text { on demographic } \\
\text { and intent }\end{array}$ & $\begin{array}{l}\text { To determine the degree } \\
\text { of moral distress } \\
\text { experienced by paediatric } \\
\text { providers from different } \\
\text { professional groups and } \\
\text { working in different } \\
\text { clinical settings } \\
\text { To describe the } \\
\text { relationship of moral } \\
\text { distress to paediatric } \\
\text { provider intent to leave }\end{array}$ & $\begin{array}{l}\text { Both physicians and nurses } \\
\text { experience moral distress } \\
\text { (percentage, describe) } \\
\text { 'Aggressive' burdensome } \\
\text { end-of-life care not } \\
\text { considered appropriate is } \\
\text { commonly associated with } \\
\text { moral distress }\end{array}$ & $\begin{array}{l}\text { Moral distress } \\
\text { 'Aggressive } \\
\text { treatment' } \\
\text { - Teamwork }\end{array}$ & $\begin{array}{l}\text { - }<30 \% \text { response rate } \\
\text { across all paediatric and } \\
\text { neonatal professionals } \\
\text { Responses from single } \\
\text { organisation }\end{array}$ & $\begin{array}{l}\text { Strategies that help } \\
\text { providers recognise morally } \\
\text { distressing situations when } \\
\text { experienced }\end{array}$ \\
\hline
\end{tabular}




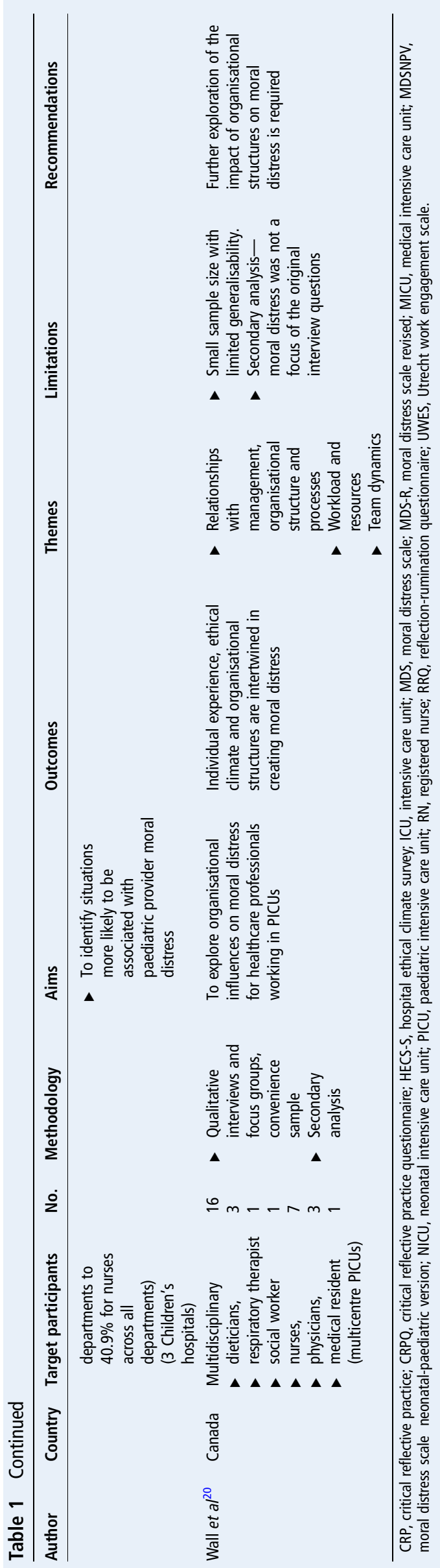

various healthcare professionals within the organisational structures, rather than focusing on the individual experiences of a particular healthcare professional. Such studies into ethical climate were in the minority.

\section{DISCUSSION}

In common with the adult nursing literature, moral distress within NICUs and PICUs most commonly results from disproportionate interventions perceived to not be in the child's best interests, ${ }^{11} 1719$ often within a negative ethical climate. With an increasing reliance on life-sustaining technology within intensive care, moral distress is a significant issue for healthcare professionals working in these environments. However, research has been hindered by unclear definitions of the term, small sample sizes and poorly designed studies that frequently lack a multidisciplinary approach.

Despite the large amount of theoretical and increasing empirical literature (especially in adult nursing literature) the term moral distress is not commonly used in clinical practice, making empirical research and direct enquiry difficult. Janvier et al ${ }^{12}$ instead use the term 'ethical confrontations'. While this term captures the moral component and suggests some form of disagreement, the term may be too broad, encompassing moral dilemmas. At times the difference between moral distress and moral dilemmas may be subtle, but it is important. In moral dilemmas, there are competing ethical principles, but no single principle clearly outweighs any another in that situation. This can create distress related to uncertainty about the right course of action. By contrast, in moral distress characteristically the right course of action is clear, but there are barriers or constraints which prevent healthcare professionals from taking this course of action. Moral distress therefore challenges personal moral integrity, resulting in the negative consequences to self and patient care. Hefferman and Heilig ${ }^{19}$ specifically sought responses about moral dilemmas, yet many of their examples are of moral distress, demonstrating the terms have been conflated. Lee and Dupree ${ }^{14}$ have used a much more stringent definition of moral distress, whereby cases must demonstrate an external constraint impacting action and the 'right' action not being taken. Additionally, their study sought unprompted expressions of moral distress to prevent measurement bias, using content analysis of staff experiences surrounding the death of critically ill patients. The study is useful in describing that not all distress surrounding the death of a child is moral distress, and such emotions can be an important expression of humanity. Common terms and framing of moral distress within different healthcare settings will strengthen a meaningful discussion and collaboration between disciplines.

Three themes featured commonly within the literature: causes of moral distress, relational dynamics between healthcare professionals within different settings or ethical climate and the impact of moral distress over time. The primary causes of moral distress in these studies were perceived disproportionate care, considered not in a patient's best interests and a perceived inability on the part of the healthcare professional to advocate for the child. The advancement of technology per se was often a source of ambivalence among (particularly nursing) healthcare professionals: its availability is viewed as a driving force behind the provision of disproportionate care that leads to moral distress. However, these are only apparent causes; the underlying causes relate to the ethical climate within the unit-the dynamics that occur between individual healthcare professionals and the organisational structures within which they work. 
Despite studies acknowledging that moral distress occurs in other healthcare disciplines, ${ }^{4}$ nurses remain the main focus of empirical research. Molloy et $a l^{16}$ justify this imbalance by stating that nurses are the frontline workers, representing the largest number within the healthcare team. The negative impact of moral distress on work engagement ${ }^{21}$ and job retention ${ }^{22}$ provides further justification. Yet the prevailing attitude is that nurses are particularly vulnerable because of the nature of nursing as a moral endeavour, the intimacy of the nurse-patient relationship, and the role of nurses' ${ }^{4}$ Despite efforts in collaboration, physicians are still depicted as upholding the 'goals of "saving life" and "furthering the advancement of science" often support[ing] continued technologic interventions beyond the comfort level of the nurse', and 'causing harm instead of providing comfort and dignity to patients at the ends of their lives'. 4 Nurses are thus presented as victims of the 'aggressive care': the physician is the perpetrator, responsible for the treatment plan. Medical literature, in contrast, tends not to use the term moral distress. Rather, the terms 'dilemma' or 'ethical confrontation' are used despite clear examples of constrained responses to moral judgements.

Such distinctions between nursing and medical staff are unwarranted. Solomon et $\mathrm{al}^{11}$ found $38 \%$ of critical care physicians and $48 \%$ of nursing staff reported acting against their consciences. Trotochaud et $a l^{19}$ also found no statistical difference between physician and nursing moral distress within critical care staff. This is despite Trotochaud et al using the MDS-R, a scale that is a more concise (21 items) version of Corley's original $\mathrm{MDS}^{23}$ that measures the frequency and intensity of moral distress. The MDS-R was designed for both multivariate research and clinical use, and involves six parallel versions (adult/paediatric populations, and for nursing, physician and other healthcare professionals). ${ }^{24}$ Yet its conceptualisation of moral distress appears limited and potentially underestimates the degree of moral distress experienced by physicians. Its poorer reliability in physicians ${ }^{24}$ limits comparisons between healthcare professionals. As the multifaceted causes of moral distress are further delineated, the instrument will need to be revised to increase its sensitivity for different providers and settings. ${ }^{9}$

An emphasis on ethical climate ${ }^{71520}$ rather than on psychological aspects of moral distress has been a relatively recent advance in moral distress literature. Sauerland et $\mathrm{al}^{7}$ used Olson's 26-item Hospital Ethical Climate Survey (HECS) to measure how hospital nurses perceive their work setting, by addressing five factors reflecting nurses' relationships with peers, patients, managers, physicians and the hospital. ${ }^{25}$ Though the nurses described their environment as moderately ethical, the HECS statement reflecting involvement in treatment decisions was among the lowest-scoring items. This implies that where there are ethical concerns, nurses may feel unable to voice their views as they see themselves as bearing little influence, contributing to moral distress. ${ }^{7}$

It is noteworthy that empirical research focusing on nursing staff frequently calls for increased collaboration, yet the vast majority of these studies fails to consider the ethical climate or capture the perspectives of other healthcare professionals. Wall et al's study ${ }^{20}$ is therefore important in providing a multidisciplinary perspective, 'revealing that organisational characteristics impact all healthcare providers, although they do so in different ways, depending on relative organisational power, position and role.' Wall et al acknowledged that 'having a voice and being heard were common needs.' Importantly, parental views (and their moral distress) were notably absent from the discussions of included studies (though parental moral distress was not sought in the search strategy).

Education has been an alternative focus for potential interventions with very mixed results. Some studies suggest that further education exposes staff to additional ethics education that increases the participant's moral sensitivity and thus predisposition to moral distress. ${ }^{7} 26$ Conversely, it may be reasonable to think that improved education regarding the outcomes of patients, the degree of uncertainty of certain conditions and appropriate pain control in intensive care patients leads to empowerment to voice and articulate concerns in a constructive manner. Lawrence et $a l^{21}$ found a relationship within NICU nurses between education level and Critical Reflective Practice (CRP) - defined by the authors as 'being mindful of self within or after professional practice situations', for example, reflecting on moral sensitivity and understanding personal motivations for action. However, this relationship was not evident in the PICU or medical intensive care unit (MICU) populations. Sauerland et al found that MDS scores were lower in paediatric/neonatal nurses despite $77 \%$ holding a bachelor's degree or higher compared with slightly more than $50 \%$ in the adult setting. The majority of researchers, however, have reported that there was no relationship between the experience of moral distress and characteristics such as age, religion, level of education and marital status. ${ }^{4}$

Clinical acumen, and not just years worked or degree obtained, must also be considered in assessments of education. Janvier et $a l^{12}$ examined the impact of clinical knowledge that influences assessment of a patient's 'best interest'. Residents and nurses who were inaccurately pessimistic about neonatal outcomes had higher thresholds for resuscitation at the limits of viability. However, while the pessimistic residents experienced fewer ethical confrontations, pessimistic nurses conversely experienced more. Improving knowledge of outcomes to combat moral distress has been relatively underexplored in a literature that has focused on hierarchical interactions. Yet in a field where there is genuine uncertainty, subjective assessments of pain and suffering and a duty to progress medical knowledge and practice, it is unreasonable to expect that education alone is sufficient to overcome moral distress.

The key may be in understanding how experiences of moral distress change with respect to time and in response to the evolving dynamics of the patient, his or her family and the institutional climate-yet no longitudinal studies directly examining moral distress were identified. Epstein has proposed at a theoretical level that moral distress for an individual will increase with repeated exposure to distress (the 'crescendo effect)'. Conversely, it may be hypothesised that continued exposure leads to desensitisation and thus reduced moral distress. No published studies support either view: there is no association between years of practice and moral distress. Nor can it be assumed that years of practice equates to exposure to morally distressing situations. Healthcare professionals for whom moral distress has a highly negative impact may abandon the intensive care unit (ICU) setting to provide care in less morally challenging environments.

It is conceivable that the degree of moral distress on a unit would vary with time, depending on the cases in the unit, how firmly moral views are held by individuals and how responsive the ethical environment is to the distress. Thus the Lee and Dupree study, ${ }^{18}$ which interviewed participants after the death of a child (mostly following redirection of care), may underestimate the degree of moral distress experienced by staff at other points in time. As moral distress is generally experienced during 
perceived overtreatment rather than undertreatment, ${ }^{13}$ the study may be missing the patients who caused the greatest moral distress in the unit-for example, patients kept alive 'at all costs' as per the families' wishes. Some of the participants describe disquiet, if not moral distress, at some point prior to the patient dying. The death of the patient had however brought resolution to the distress-thus Lee and Dupree conclude that participants "ultimately felt that the team had done "right" by the child and family' (emphases added). Evaluating the nature of moral distress longitudinally may provide valuable insights into the true intensity and frequency of moral distress in ICUs as well as highlight the impact of changing dynamics and interactions within the ethical climate.

\section{Implications}

Despite variations in definitions of moral distress, a commonly held conclusion from the above studies is that rather than trying to define moral distress we should be looking to study interven-

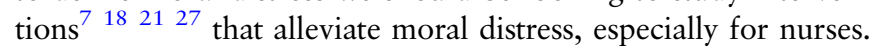
For example, Cavaliere recommends that we 'specifically test actions and find solutions that will prevent futile care as well as to protect and defend nurses from the pain of powerlessness and participation in such care that appears to be harming the patient'. ${ }^{4}$ This step towards interventions may be somewhat premature for, as is evident in this review the inclusions of all stakeholders' perspectives remains lacking. Even studies addressing ethical climate, for example, Sauerland et $a l^{7}$ have not adequately looked at the interplay of other healthcare professionals nor the perspectives of families within the same environment. Interventions based on a singular or limited perspective have the potential to decrease the impact of collaboration and exacerbate the differences between healthcare providers. A mutual understanding of perspectives from all stakeholders is required to improve the ethical environment and ultimately decrease moral distress for all members of the healthcare team, including the parents.

With the advancement of medicine, it is difficult to imagine eliminating moral distress altogether. It must be asked whether, in our pluralistic world with uncertain outcomes, the elimination of moral distress is even desirable. ${ }^{28}$ The answers to some difficult ethical dilemmas are often not black and white and should cause some distress and unease in both healthcare professionals and parents. It is hard to navigate between 'doing too much' and 'not enough'. How much moral distress is necessary, so that we continue asking ourselves the right question and challenging ourselves when there are new treatments available? If some moral distress is necessary for progress, how do we deal with this 'useful baseline moral distress' or healthy ethical confrontation, to be able to live with 'moral peace' for all involved?

\section{Limitations}

The variety of mixed methodologies and populations makes direct comparisons of studies and generalisation of result difficult. However it is valuable in demonstrating the scope of research in this area. Parental perspectives are an important component of end-of-life discussions but are beyond the scope of this discussion.

\section{CONCLUSIONS}

Moral distress continues to affect the care of paediatric and neonatal intensive care patients. Empirical data on the moral distress of multidisciplinary populations remains sparse within NICUs and PICUs. Meaningful dialogue has been hindered by differing expressions of moral distress across healthcare professions and a lack of understanding of how moral distress changes with time. Further research is required to elucidate (or investigate) the perspectives of all team members, including parents, at various points along the decision-making process to enable effective interventions against 'unhelpful' moral distress.

Contributors The first author formulated and conducted the search strategy. The final author reviewed the search strategy, abstracts and full text articles. All authors reviewed the included full text articles, ensured consensus was reached on all included articles and contributed to editing and formulation of the final manuscript.

Competing interests None declared.

Provenance and peer review Not commissioned; externally peer reviewed.

\section{REFERENCES}

1 Jameton A. Nursing practice: the ethical issues/Andrew Jameton; with a foreword by Ingeborg G. Mauksch. Englewood Cliffs, New Jersey: Prentice-Hall, 1984.

2 Epstein EG, Hamric AB. Moral distress, moral residue, and the crescendo effect. J Clin Ethics 2009;20:330-42.

3 Carse A. Moral distress and moral disempowerment. Narrat Inq Bioeth 2013;3:147-51.

4 Cavaliere $T$, Daly B, Dowling $D$, et al. Moral distress in neonatal intensive care unit RNs. Adv Neonat Care 2010;10:145-56.

5 Hardingham LB. Integrity and moral residue: nurses as participants in a moral community. Nurs Philos 2004;5:127-34.

6 Sundin-Huard D, Fahy K. Moral distress, advocacy and burnout: theorizing the relationships. Int J Nurs Pract 1999;5:8-13.

7 Sauerland J, Marotta K, Peinemann $M$, et al. Assessing and addressing moral distress and ethical climate part II: neonatal and pediatric perspectives. Dimens Crit Care Nurs 2015;34:33-46.

8 Moher D, Liberati A, Tetzlaff J, et al. Preferred reporting items for systematic reviews and meta-analyses: the PRISMA statement. PLoS Med 2009;6:e1000097.

9 Whitehead PB, Herbertson RK, Hamric AB, et al. Moral distress among healthcare professionals: report of an institution-wide survey. J Nurs Scholarsh 2015;47:117-25.

10 UK C. Critical Appraisal Skills Programme. Secondary Critical Appraisal Skills Programme, 2013.

11 Solomon MZ, Sellers DE, Heller KS, et al. New and lingering controversies in pediatric end-of-life care. Pediatrics 2005;116:872-83.

12 Janvier $A$, Nadeau $S$, Deschênes $M$, et al. Moral distress in the neonatal intensive care unit: caregiver's experience. J Perinatol 2007;27:203-8.

13 Solomon $M, O^{\prime}$ Donnell $L$, Jennings $B$, et al. Decisions near the end of life: professional views on life-sustaining treatments. Am J Public Health 1993:83:14-23.

14 Hefferman P, Heilig S. Giving 'moral distress' a voice: ethical concerns among neonatal intensive care unit personnel. Camb Q Healthc Ethics 1999;8: $173-8$.

15 McGibbon E, Peter E, Gallop R. An Institutional Ethnography of Nurses' Stress. Qual Health Res 2010;20:1353-78.

16 Molloy J, Evans M, Coughlin K. Moral distress in the resuscitation of extremely premature infants. Nurs Ethics 2015;22:52-63.

17 Sannino $\mathrm{P}$, Giannì ML, Re LG, et al. Moral distress in the neonatal intensive care unit: an Italian study. J Perinatol 2015;35:214-17.

18 Lee KJ, Dupree CY. Staff experiences with end-of-life care in the pediatric intensive care unit. J Palliat Med 2008;11:986-90.

19 Trotochaud K, Coleman JR, Krawiecki N, et al. Moral distress in pediatric healthcare providers. J Pediatr Nurs 2015;30:908-14.

20 Wall S, Austin WJ, Garros D. Organizational Influences on Health Professionals' Experiences of Moral Distress in PICUs. HEC Forum 2015. 1-15.

21 Lawrence LA. Work engagement, moral distress, education level, and critical reflective practice in intensive care nurses. Nurs Forum 2011:46:256-68.

22 Sauerland J, Marotta K, Peinemann MA, et al. Assessing and addressing moral distress and ethical climate, part 1. Dimens Crit Care Nurs 2014;33:234-45.

23 Corley M, Elswick R, Gorman $\mathrm{M}$, et al. Development and evaluation of a moral distress scale. J Adv Nurs 2001;33:250-6.

24 Hamric $A B$, Borchers $C T$, Epstein EG. Development and testing of an instrument to measure moral distress in healthcare professionals. AJOB Prim Res 2012;3:1-9.

25 Olson L. Hospital nurses' perceptions of the ethical climate of their work setting. Image J Nurs Sch 1998;30:345-9.

26 Penticuff $\mathrm{JH}$, Walden M. Influence of practice environment and nurse characteristics on perinatal nurses' responses to ethical dilemmas. Nurs Res 2000;49:64-72.

27 Catlin A, Armigo C, Volat D, et al. Conscientious objection: a potential neonatal nursing response to care orders that cause suffering at the end of life? Study of a concept. Neonatal Netw 2008;27:101-8.

28 Lantos JD. Moral distress and ethical confrontation: problem or progress? J Perinato 2007;27:201-2. 